\title{
ALTERNATION OF STANDPOINT (ATTITUDE) IN EDUCATION SYSTEM TOWARDS A CHILD WITH SPECIAL NEEDS
}

\author{
Rita Virbalienè \\ M.Romeris universitety \\ Social Technologies faculty Sciences and Social Work institute
}

\begin{abstract}
The article represents alternation of standpoint (attitude) in reformed education system towards a child with special needs. In the theory and practice of integrated education so far is paid relatively low attention towards improvement of social interaction between disabled scholars and teachers, analysis and elimination of the reasons of prejudices, alternation of positive attitude. Very relevant issue in Lithuania, as well as throughout Europe, is slow alternation of attitude towards integration of children with special needs into the system of general education. Although experience that was gained in Lithuania is fair enough, good results gained during organization of methodological, scientific research work in the field of special and social pedagogy, however there is a lack of works which would analyse the attitude of general education teachers towards the opportunities of special children's education in the context of alternation of education system.
\end{abstract}

Keywords: special education needs, special education, attitude towards integration.

\section{Introduction}

In Lithuania, as well as throughout Europe, very relevant issue is alternation of attitude towards integration of children with special needs into the system of general education. After Lithuania's becoming an independent state and its recognition of the principle of equal opportunities there have appeared realistic assumptions for a person with limited opportunities to act and to organize his or her life in accordance with the same principles as all people do. After all a person, an individual can't exist alone. An essential assumption for a fullfledged existence is social life Vanier, J., (1998), therefore during all stages of humanity development the place of individual in the society, the value of the roles played by him, interpersonal relationships are considered as one of the most relevant issues. According to Ruskus, J., (1997), Gedviliene, G. (1997), mutual interaction determines an opportunity of disabled person to live full-rate life: readiness of community members to accept different person and ability of the person with limited opportunities to act free. These two essential conditions which can guarantee full-fledged interoperability can't occur spontaneously. Cognitive and confidence environment that emerges during communication and acting together is essential for this.

In the sources of literature integration is defined as the process of alternation that encourages new attitude towards entire education process. Democratic society realizes integration as natural and irreversible phenomenon. Often attitudes towards and assessments of integration are very different, and special education is often understood as formal transfer of children with special needs 
from one institution into another without provision of qualified help. The system of special education in Lithuania, like in any other country, is peculiar and determined by particular historical and cultural factors, after all every country has very different experience in this field. Public attitude towards children with special education needs forms on the basis of the country's traditions, philosophical attitudes, the policy of education and training. Special education is based on the principles of general and special pedagogics. It is very important that during formation of state policy of education wouldn't be forgotten and formed positive attitude towards integration of disabled people and it would be pursued providing equal conditions to every child for education having regard for his powers and abilities.

During Lithuania's integration into rapidly changing global society it is essential to make radical modernization of educational content and to improve its quality. One of the purposes of Lithuanian education conception is to educate a person who would be able to respect and acclimatize the changing social, economic life. During the period between 1991 and 2014 in Lithuania was widely analysed an attitude towards integration of disabled persons; alternation of standpoint towards disabled persons during historical evolution; attitudes of parents, contemporaries and teachers in regard of children with special needs; influence of religion and art; opportunities, principles of inclusion of children with special needs into the system of education, institutions of general education and forms of education, also obstacles and problems; recognition of disabled persons' special needs; provision of special assistance and other issues. These topics were widely analysed in the works of the scientists from various countries: Angermeyr, M.C., Matschinger, H. (2005), Angermeyer, M.C., Schulze, B., Dietrich, S. (2003), Balton, J. (2003), Hallahan, M.E., Pliner, S. (1983), Hallahan, D.P., Kauffman, J.M.,(2003), and others. In Lithuania these topics were analysed by Ališauskas, A., Ambrukaitis, J. other (1993), Adomaitiene, R., Samsoniene, L., (1997), Ambrukaitis, J. (1996, 1997, 1997), Ambrukaitis, J., Ruškus, J. (2003), Balciunaite, R. (2003), Barkauskiene, R. (2004), Gibaciauskas, E., Merkys, G. (2003), Gudonis, V., Gailiene, I., (1996), Gudonis,V. (1994, 1996, 2004), Gudonis, V., Novogrockiene, E. (2000), Gudonis, V., Valantinas, A., Strimaitiene, L., (2003), Galkiene, A. (1999, 2001, 2003, 2005), Grinceviciene, V. (2006), Kafemaniene, I., (2001), Ruskus, J. (2002, 2003), Samsoniene I. (2006) and other scientists.

However, in the theory and practice of integrated education of children with special needs so far very little attention is paid towards improvement of social interaction between disabled learners and teachers, examination and elimination of the reasons of prejudices, formation of positive alternation of standpoint.

Topicality of the topic that is analysed in the article is determined by rapidly proceeding processes of integration of disabled children and necessity of more rapid alternation of public standpoint towards disabled children. The model of integration of children with special needs into the school of general education is 
created by public standpoint towards disabled persons and educational environment.

The object of research is alternation of standpoint (attitude) towards disabled children and education system (from special education to inclusion). The purpose of the research is to present the aspects of alternation of teachers' attitude towards disabled children.

Empirical methodology and data analysis. The methods of research, theoretical: the analysis of scientific literature and documents, also the analysis of quantitative research, statistical data (using standard statistical packages). Quantitative analysis was performed using semi-closed questionnaire, teachers received questionnaires containing narrow, specific questions, which were answered unambiguously. At the end of the questionnaire teachers were able to write a letter to the researchers and to submit proposals how to perform further alternation of education system in order to ensure the least possible obstacles for the integration of disabled children into the system of education. 2280 teachers of various age (from 18 to 50 and older) who work in various institutions of education ( $1 \%$ in nursery, $30 \%$ in nursery-school, $66 \%$ at school, 35 in special institutions and else-where) participated in the research.

The research was performed on the basis of the main methodological attitudes, the ideas of humanistic philosophy which validate democratic relations of people from various social groups, ensure human freedom, personal selfexpression and education of natural powers. The work is based on humanistic theory of education Rogers, C., (1961) hat emphasizes human freedom and independence, the pursuit for self-analysis, education of natural human abilities and realisation of his potential opportunities, also unconditional positive standpoint towards other person. The central standpoint of C.Roger's client in the process of education brings the learner into the central position of this activity. It was attempted within the research to realize the attitude of S.Salkauskis that through pedagogy must be realised all cultural values and created the "system of education of fullness", also was followed outlook and ideology which are considered as the pursued purpose education. Public attitude towards integration of disabled people is determined by many factors. First of all the attitude depends on the public opportunities, the level of development, economics, relations between various groups of people, political, moral, religious, philosophical public factors. Education, scientific, health, cultural and other level of development strongly influence formation of standpoint. The higher level of development in the country causes the bigger tolerance and more favourable standpoint towards integration of disabled people. 


\section{Alternation of standpoint (attitude) towards integration of disabled people in the stages of historical development}

In the stages of historical development the standpoint towards integration of disabled people, starting from the absolute isolation and inclusion, was distinctly changing. According to Ruskus, J. (2002) "in ancient times people with disabilities were simply destroyed (in case of body disabilities) or were left for slavery (in case of mental disability), during Middle Ages they were assigned with the role of paupers or even sorcerers, and in the predawn of the $20^{\text {th }}$ century, during scientific expedition the disabled persons were placed in special institutions".

In every country for longer or shorter period dominated medical model that is currently clinical-corrective. According to Ruskus, J. (2002) "clinical standpoint towards disability and people with disabilities has formed several hundred years ago when philosophers have distinguished a body from soul, when were determined biological and anatomical, physiological, but not religious or moral reasons of disorders. Therefore even until the middle of the $20^{\text {th }}$ century clinical standpoint that was initiated by E.Seger was very progressive. Were rejected all supernatural explanations of disability, was started orientation towards correction of disability. Were established many institutions which provided special medical and educational assistance to people with disabilities.

According to Galkiene, A. (2005), the beginning of segregated education of scholars with special needs in Lithuania should be associated with introduction of compulsory primary education in 1920. According to the author, after the children with different abilities have gathered together in schools, there has highlighted powerlessness of education system to educate everybody in one class. A lack of pedagogical experience prevented from achievement of desired results and it was concluded that the best way to educate people with special needs in separate classes and, even better, in separate institutions. During that period in Lithuania was started establishment of special schools, boardingschools, asylums, that meant isolation of disabled people from the society not just physically, geographically, but also socially. This phenomenon is called institutionalization, it is also described by Galkiene, A., (2005) as external differentiation.

After restoration of independence in Lithuania it is attempted gradually move from medical clinical-corrective model to the model of integration (inclusion) of disabled people. The current Lithuanian legal framework regulating the rights of persons with disabilities, education of disabled people, their integration to the society is very well organized, and thus is formed positive standpoint towards integration of disabled people. However this process is quite slow and problematic, because implementation of adopted legislation is underfinanced, 
therefore the public standpoint towards disabled learners is changing very slowly.

According to Leonavicius, V., (2004), children with special needs need appreciation from the side of teachers and contemporaries, however they don't want to stand out from the ranks of their class-mates receiving different task, additional assistance. Disabled child always feels better when he is not forced by surrounding environment to compete, compare and align. More favourable conditions needed for the child's personality dissemination are created, the better being of the child is guaranteed. Disabled children do not form some separate group that stimulates particular desire or reluctance to communicate from the side of contemporaries. So, disability isn't the essential element that influences children's communication with their contemporaries. Children's desire to go to school, to participate in various events which take place at school and in the class reflect well-being of children with special needs.

Galkiene, A., (1999) has conducted a study of teachers and has showed what form of education is considered by teachers as the most reasonable for education of children with disability and has answered the question why public integration of disabled people is valuable. According to Galkiene, A., the most important worth of integration is an opportunity for disabled children to live at their parents' home. It is natural because child's natural law is to feel safe under the care of his mother and father until he will be able to self-manage his life. Acknowledgement of life is critical both for healthy and disabled children, because inter-human relation is unavoidable during all life.

According to Grinceviciene, V.,(2006), the number of children with special needs is constantly increasing. Their social status depends on the position of people who raise them - parents, teachers, medics. Various researches indicate that children with special needs can integrate into society and interact with others, to take over the cultural heritage of the nation. Thus, children with special needs shouldn't be educated in isolation as is customary in our society: they should develop and educate in normal environment, to communicate both with each other and with healthy children. Such integrations are discussed in the Law of Special Education.

However, after analysis of the data rendered by the Department of Statistics regarding integration of children with special educational needs into the classes of general education we notice that the number of integrated children is decreasing. 


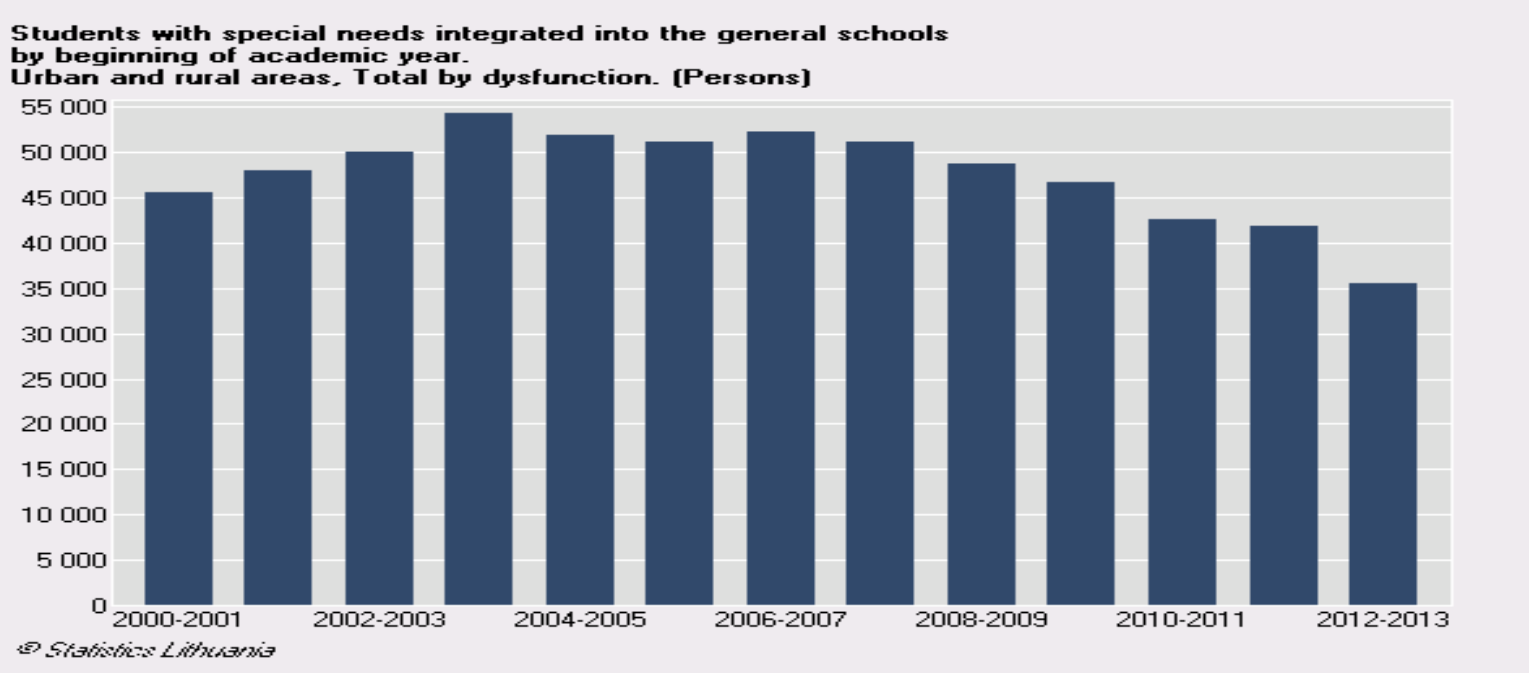

Fig.1 Students with special needs integrated into the general schools 2000-2014

\section{The teachers' standpoint towards integration of children with special needs}

The purpose of the performed quantitative research was to reveal the standpoint of the teachers who are working in various educational institutions towards integration of children with special needs into the institutions of general education. 2280 teachers of various age (from 18 to 50 and older), who work in various institutions of education (1\% in nursery, 30\% in nursery-school, $66 \%$ at school, 35 in special institutions and elsewhere).

Answering to the question Whether the children with minor, modest, considerable, very considerable disabilities could also educate together with healthy children? I oppose to integrated education (the respondents were able to select one option of response) the respondents supported the integration of children with minor disabilities into the schools of general education: agreed: $67 \%$ of women and $7 \%$ of men; do not agree: $4 \%$ of women and $0,3 \%$ of men; agree only under certain conditions: $16,7 \%$ of women and $0,7 \%$ of men.

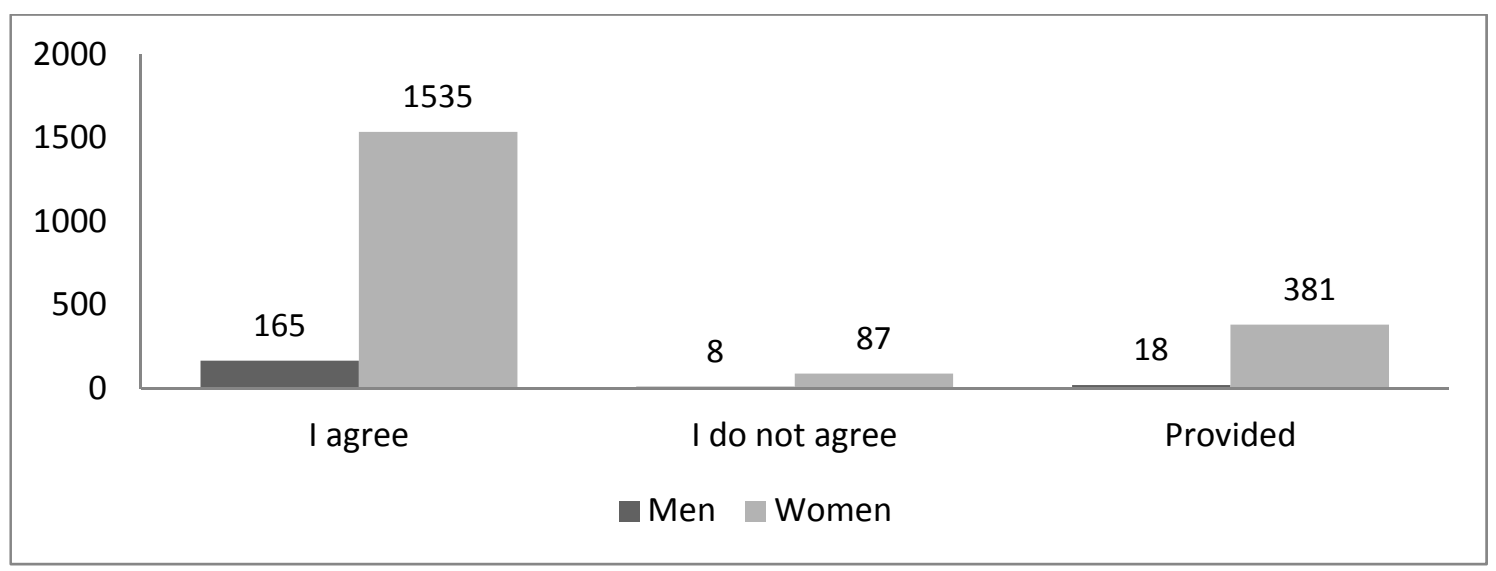

Fig.2 Integration of children with minor disabilities into the schools of general education 
Supported integration of children with modest disabilities into the school of general education: agree: $47,3 \%$ of women and $4,25 \%$ of men; do not agree: $26 \%$ of women and $3 \%$ of men; agree only under certain conditions: $15 \%$ of women and $0,7 \%$ of men.

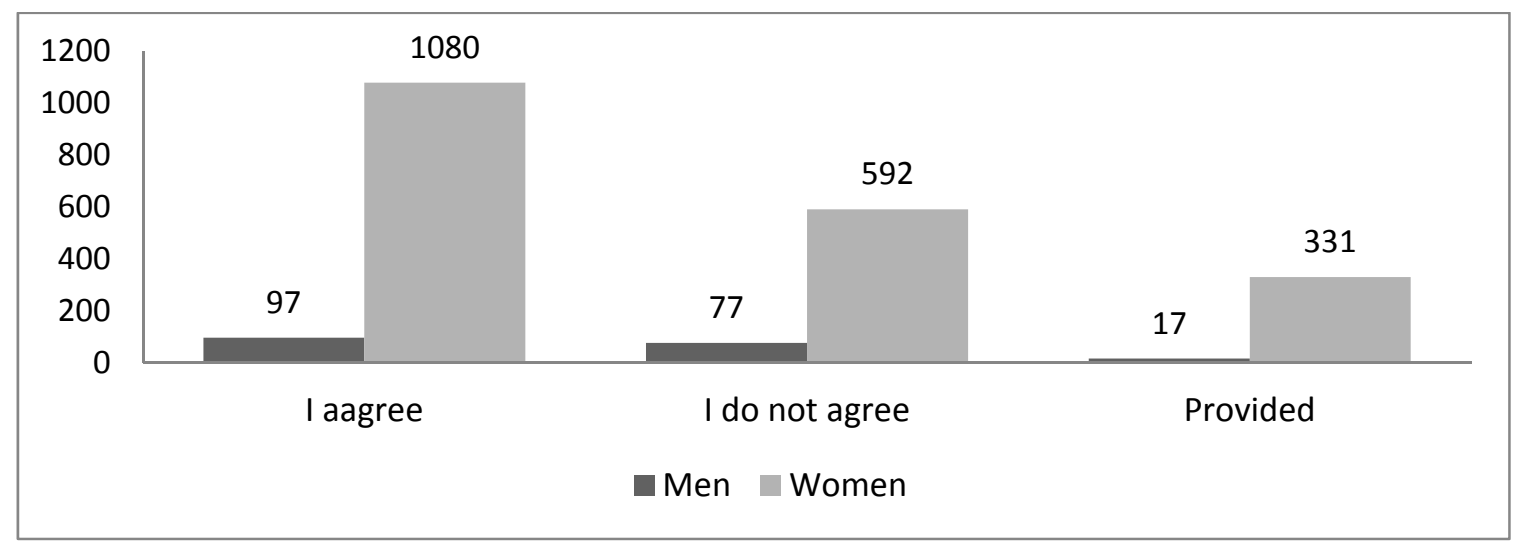

Fig. 3 Integration of children with modest disabilities into the school of general education

Supported integration of children with considerable disabilities into the school of general education: agree: $6 \%$ of women and $0,5 \%$ of men; do not agree: $73,8 \%$ of women and $7,4 \%$ of men; agree only under certain conditions: $7,9 \%$ of women and $0,3 \%$ of men.

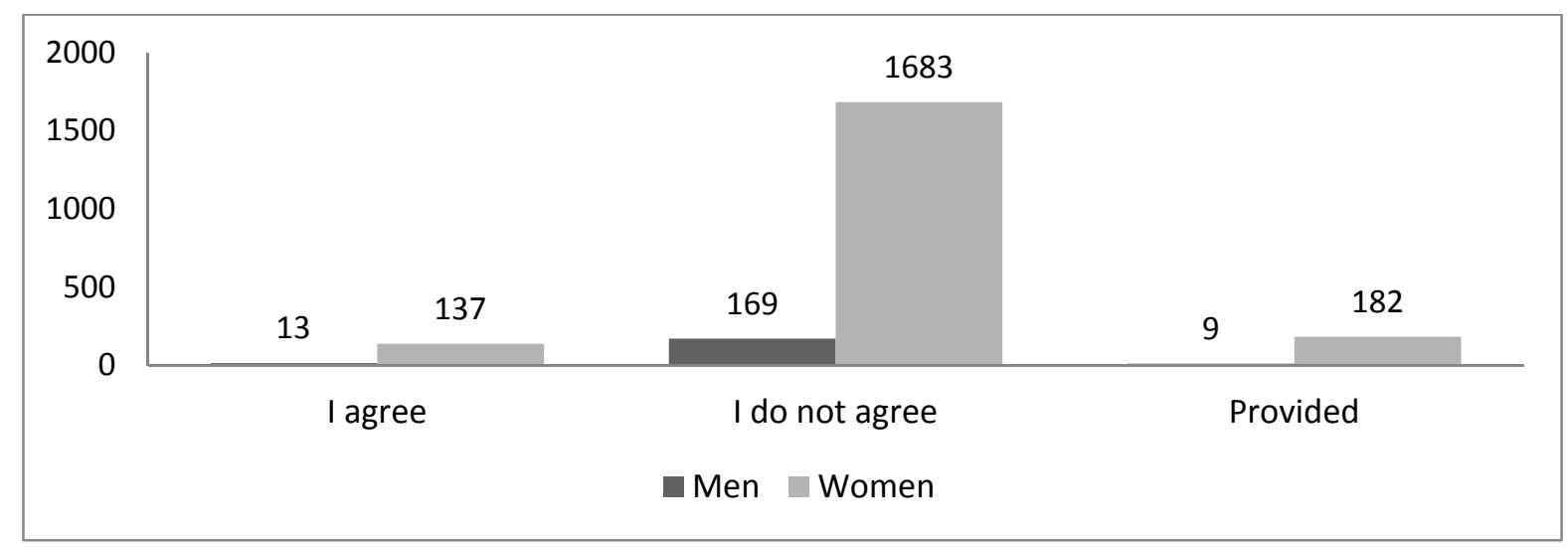

Fig.4 Integration of children with considerable disabilities into the school of general education

Supported integration of children with very considerable disabilities into the school of general education: agree: $67 \%$ of women and $7 \%$ of men; do not agree: $4 \%$ of women and $0,3 \%$ of men; agree only under certain conditions: $16,7 \%$ of women and $0,7 \%$ of men. 


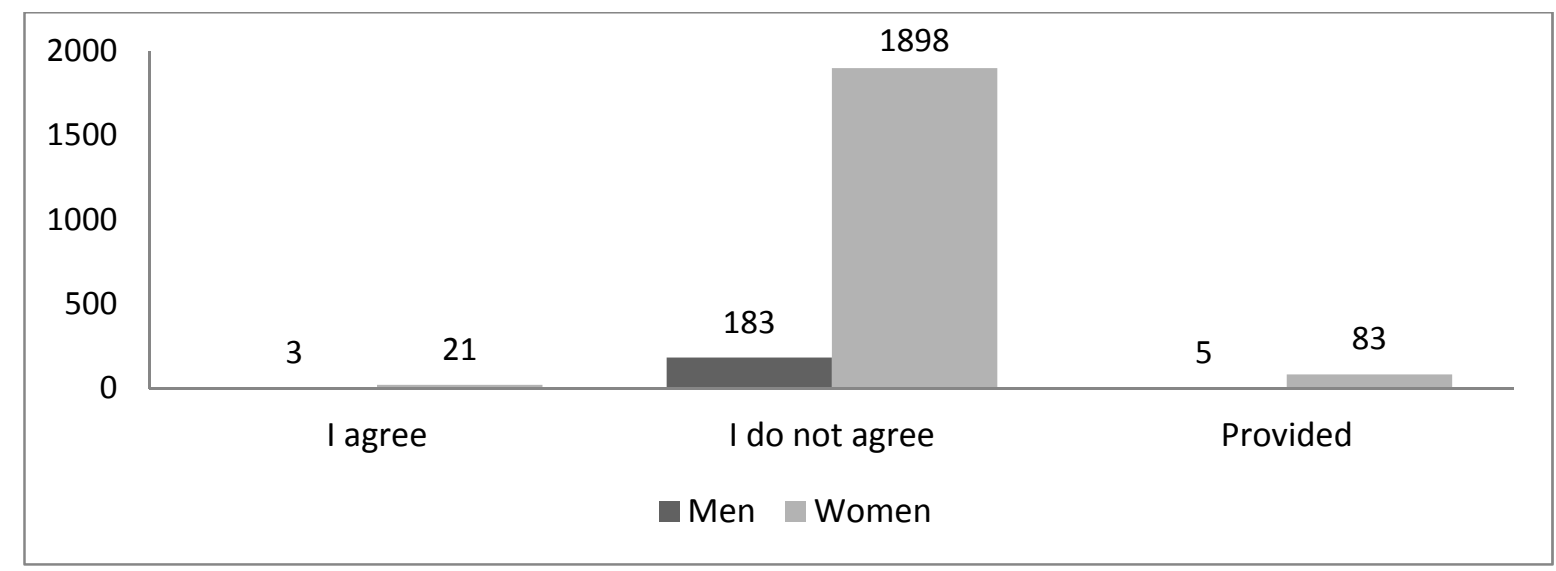

Fig. 5 Integration of children with very considerable disabilities into the school of general education

The obtained results of the research suggest that standpoint towards integration of children with special needs into the school of general education is positive just partly because the results of the research have revealed that not all the teachers who work at school support integration only of those children who have moderate and modest disabilities with special educational needs. More than a half of the teachers who have participated in the research do not support integration of children with considerable and very considerable disabilities into the institutions of general education.

The teachers who have filled in the questionnaire of the research had an opportunity to write a letter to the researchers and to submit proposals or to express their fears regarding further alternation of educational system avoiding obstacles for the integration of children with special needs into the system of education.

Among the 2280 respondents who participated in the survey 1216 have written their letters to the researchers, this represents $53,3 \%$ of all the teachers who participated in the research, i.e. $49,6 \%$ of women and $3,6 \%$ of men.

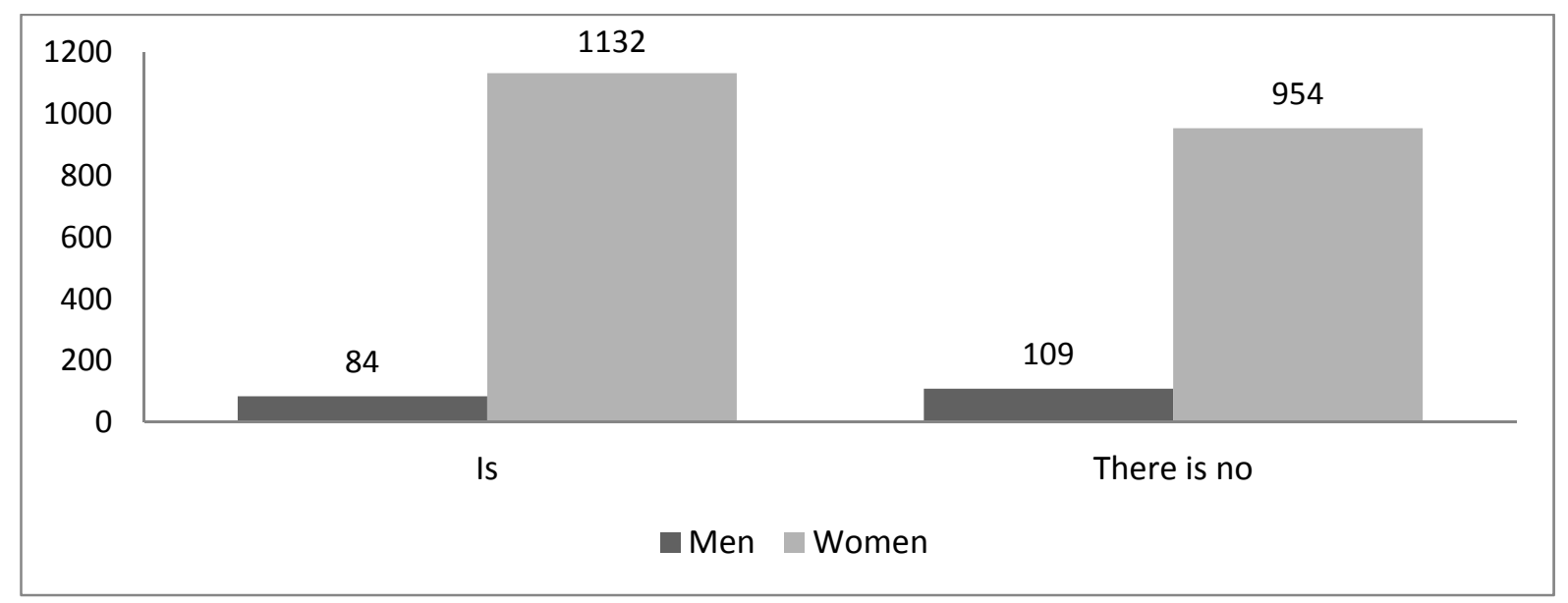

Fig.6 Written their letters to the researchers 
In their letters the teachers suggested that there is a need to change the standpoint towards the integration of disabled children because it is still very negative; the integrated classes would contain less children; special educators fail to teach their pupils fitting to the time limits and suggest that they would be able to teach the children with special needs only individually; there is a lack of special and social workers, teachers' assistants; more resources should be allocated for the education and awareness of families who are raising children with disability; the disabled children should be as earlier as possible incorporated in the education system; to prepare more methodological and information measures needed for a work with children with special needs; to organise teachers' training and to inform them how they should work with disabled children; to adapt premises; to prepare special measures. Some teachers in their letters have informed that the school that is the working place of that particular teacher "...is unsuitable for the absolute integration of disabled children because classrooms, furniture, illumination aren't adopted for that purpose, there are no appropriate measures and etc..." The teachers in their letters suggest to work more focused on healthy children and to help them to become more tolerant and to change their attitude toward disabled people. Some teachers express doubts in their letters, whether it would be acceptable to integrate children with very considerable disabilities into schools and suggest that there should be integrated only the children with moderate or only physical disability. I think that the analysis of teachers' letters should be more detailed and this should be done in the next works.

\section{Conclusions}

1. The teachers' standpoint towards the integration of children with special needs into the school of general education is positive just partly because the results of the research have revealed that not all the teachers who work at school support integration of children with special needs. School environment is insufficiently adopted for the education of children with special needs.

2. The research has revealed that teachers have expressed many doubts regarding success of integrated education. They think that society, school and scholars aren't prepared for this, the appropriate conditions aren't warranted, there is a lack of measures and textbooks, also a lack of special educators and teachers' assistants. These children need constant support. Teachers aren't able during a lesson to pay enough time and attention for the children who work under general and adapted or modified programs because the classes contain a lot of children.

3. The point of view of Lithuanian and foreign scientist, the analysis of Lithuanian legislation that regulates the system of special education suggest that the conditions of special education become more and more favourable, integration is taking place and children with special needs aren't isolated, 
they are educated in the schools of general education agreeably with their place of residence. The idea of integrated education will allow solution of one of the main tasks of the school of general education. i.e. to look back at the person who is an absolute treasure.

\section{References.}

1. Ališauskas, A., Ambrukaitis J. ir k t. (1993). Specialiuju poreikiu asmenu integracija. Mokslinès konferencijos tezès. Šiauliu Pedagoginis institutas.

2. Adomaitienè, R., Samsonienè, L. (1997). Pedagogu požiūris ì neịgaliuju mokiniu integracija bendrojo lavinimo mokyklose. Lietuvos mokyklai - 600 m.: konferencijos medžiaga.

3. Ambrukaitis, J. (1996). Specialiuju poreikiu vaiku integruoto ugdymo prielaidos// LKMA suvažiavimo darbai XVI, Vilnius.

4. Ambrukaitis, J. (1997). Specialiuju poreikiu vaikai. Šiauliai.

5. Ambrukaitis, J. (1999). Pedagogu požiūris i specialiuju poriekiu vaiku integracijal/ Specialusis ugdymas: Mokslo darbai II.

6. Ambrukaitis J., Ruškus J. (2003). Specialiuju poreikiu vaikas bendrojo lavinimo mokykloje // Specialusis ugdymas, 2 (9)

7. AAngermeyr, M.C., Matschinger, H. (2005). Labelling - Stereotipe - Discrimination. Social Psychiatry Epideniology, 40.

8. Angermeyer, M.C., Schulze, B., Dietrich, S. (2003). Courtesy Stigma/Afocus Group Study of Relatives of Schizophrenia patients. Social Psychiatry Epidemiology 38.

9. Balčiūnaite, R. (2003). Proto negalios asmenu artimuju (broliu ir seseru) tapatumo problemos socializacijos procese. Socialiniai neigaliuju aspektai: kai žmogui reikia žmogaus. Kaunas.

10. Barkauskienè, R., (2004). Tèvu ir pedagogu požiūris i vaiku, turinčiu mokymosi negaliu, psichologini prisitaikyma. Specialusis ugdymas: mokslo darbai. Nr. 2 (11).

11. Balton, J. (2003). Reducing the stigma of mental illness. Student Bmj, 11.

12. Gibačiauskas, E., Merkys, G. (2003). Pedagogu nuostata i ugdytiniu integracija ir segregaciją. Specialusis ugdymas: mokslo darbai Nr.1.

13. Gudonis, V., Gailiene, I., (1996). Adekvataus tèvu požiūrio svarba vaiko ugdymuisi// Gimtoji kalba ir jos mokymo problemos IV klaseje: Konferencijos m. Šiauliai.

14. Gudonis, V., (1994). Meno ịtaka formuojant visuomenès požiūrị ị aklą žmogų// Lietuvių katalikų mokslo akademijos XVI suvažiavimo pranešimų medžiaga. Kaunas.

15. Gudonis, V. (1996). Požiūrio svarba integruoto mokymo sąlygomis// Vaikų, turinčių specialiujų mokymosi poriekių, ir suaugusių asmenų socializacija: Konferencijos pran. Medžiaga. Šiauliai.

16. Gudonis, V.,(2004), Aklieji mene kaip specifinis nuostatų atspindys. Aklumas ịvairiose kultūrose. Vilnius.

17. Gudonis, V., Novogrockiene, E., (2000). Visuomenès požiūris ì neigaliuosius suaugusius ir specialiuju poreikiu vaikus. Specialusis ugdymas Nr.3.

18. Gudonis, V., Valantinas, A., Strimaitienè L. (2003). Bendrojo lavinimo mokyklos bendruomenès nuostatos $\mathfrak{i}$ specialiasias klases ir jų ugdytinius. Specialusis ugdymas: mokslo darbai Nr.2(9).

19. Galkienė A. (1999). Negalios vaiku ugdymas bendrojo lavinimo mokykloje //Pedagogika.

20. Galkienè A. (2001). Keli integruoto ugdymo aspektai. Vilnius.

21. Galkienė A. (2003). Pedagoginè squeika integruoto ugdymo sąlygomis. Šiauliai. 
22. Galkienè A. (2005). Heterogeniniu grupiu didaktika: specialieji poreikiai bendrojo lavinimo mokykloje. Šiaulai.

23. Grincevičienè,V., (2006). Mokinių tẻvų požiūris ị mokyklą ir ugdymo procesą . Mokslo darbai. Pedagogika, 83.

24. Hallahan, D.P., Kauffman, J.M. (2003) Ypatingieji mokiniai: specialiojo ugdymo ivadas. Vilnius.

25. Hallahan, M.E., Pliner, S. (1983). Tichers attidudes toward handicapped children: Review and synthesis. Shool psichology rewied 12.

26. Kaffemanienè, I., (2001). Specialiuju poreikiu vaikų integracija. Požiūrio problema // Specialiuju poreikiu vaiku pažinimas ir ugdymas: konferencinè medžiaga. Šiauliai.

27. Leonavičius, V. (2004). Sociologija. Kaunas.

28. Ruškus J. (2002). Negalès fenomenas. Šiauliai.

29. Ruškus J.(2003). Specialiuju poreikiu vaiku ugdymo metodologija: modeliai, metodai, kontekstai, pokyčiai, kryptingumas.// Specialiojo ugdymo pagrindai. Šiauliai

30. Samsonienè 1. (2006). Specialiuju poreikiu vaikai ir ju socialine integracija: mokomoji knyga. VU.

31. Rogers, Carl. (1961), kaip tapti asmuo: Terapeutas požiūris i psichoterapijos. Londonas.

32. Vanier J. (1998) Bendruomenè atleisti ir švęsti. Vilnius. 